\title{
Emergency management of traumatic total scalp avulsion with microsurgical replantation
}

\author{
Zhaohua Jiang, M.D., Shengli Li, M.D., Weigang Cao, M.D. \\ Department of Plastic and Reconstructive Surgery, Shanghai Ninth People's Hospital, \\ Shanghai Jiao Tong University School of Medicine, Shanghai, PRC
}

\begin{abstract}
Total scalp avulsion is a rare but serious injury often resulting in defects of the hair-bearing skin, and it may even be life-threatening. Microsurgical hair-bearing scalp replantation is the first choice for the treatment of scalp avulsion. In this article, we describe the microsurgical replantation of two cases with total scalp avulsion. The avulsed scalp involved the hairy scalp, forehead, eyelids, ears, and part of the face. Initial management in the emergency department (ED) included correction of hemorrhagic shock with early blood transfusion, intravenous rehydration, and wound compression after rapid physical examination. A full trauma and preoperative workup prior to attempts at replantation needs to be performed to exclude any associated life-threatening injuries. Good form and function of the completely avulsed tissues and organs were achieved in both cases. Successful replantations can achieve the best esthetic and functional results when compared with other procedures. In addition to the microsurgical technique, preoperative evaluation and preparation in the ED are considered to be an important part of the successful salvage of the avulsed scalp.
\end{abstract}

Key words: Emergency department; microsurgery; replantation; scalp avulsion.

\section{INTRODUCTION}

Total scalp avulsion is a rare but serious injury often resulting in defects of the hair-bearing skin, and it may even be lifethreatening. With recent advances in microsurgery and emergency management, most cases of traumatic amputations are managed with replantation by establishing revascularization. After the first successful scalp replantation reported by Miller et al. in 1976, ${ }^{[1]}$ some articles, mostly case reports, were published. ${ }^{[2-6]}$ Since that time, microsurgical replantation has been considered the first choice in the treatment of scalp avulsion. Our department has accumulated experience in successful replantation of a completely avulsed scalp. ${ }^{[7]}$ In addition to the microsurgical technique, the successful salvage of the avulsed scalp is closely related to careful preoperative evaluation and preparation in the emergency department (ED). Scalp avul-

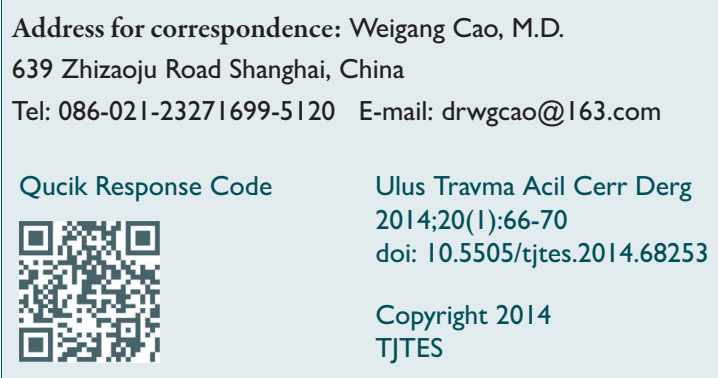

sion is potentially accompanied by hemorrhagic shock, which should be addressed first. ${ }^{[8]}$ Early blood transfusion, intravenous rehydration, and wound compression after rapid physical examination are important. A full trauma and preoperative workup prior to attempts at replantation needs to be performed to exclude any associated life-threatening injuries, such as pneumothorax, cervical dislocation and intracranial injuries.

This article aimed to present our emergency treatment experience with microsurgical replantation in two recent cases of scalp amputation, and it provides a literature-based update of the evaluation and management of avulsed scalp.

\section{CASE REPORT}

Case I- A 26-year-old woman with no pertinent medical history was brought to our ED via ambulance approximately four hours after a traumatic injury. Her hair was caught in a factory machine, resulting in avulsion of the entire hairy scalp, nasal area, forehead, left ear, and bilateral eyelids and eyebrows (Figure Ia). There was no loss of consciousness. The examination ruled out associated life-threatening cervical dislocation and intracranial injuries. After fluid resuscitation and $1000 \mathrm{ml}$ blood transfusion, the patient was brought to the operating room for immediate replantation under general anesthesia. 
According to replantation procedures established in our department, debriding the avulsed scalp, preparing the recipient site of the patient's head, and harvesting venous grafts from the lower extremity were carried out simultaneously. ${ }^{[8]}$ The avulsed scalp was placed on the underside of an overturned circular basin, carefully shaved and debrided. It was also thoroughly irrigated to remove dirt and oil. Additional lacerations were found in the corona capitis (Figure Ib). The only vessels available for microanastomoses were the bilateral superficial temporal artery and veins. Vein grafts were anastomosed to the arteries on the patient's head and veins on the avulsed scalp at the same time. All pre-replant preparation was completed (Figure Ic). Immediately after replantation and anastomosis of the completely avulsed scalp, excellent blood supply was established for all of the avulsed tissue (Figure Id). Total ischemia time was 10 hours. The dressing was changed initially four days after surgery; the scalp survived well and closed drains were removed at this time. Twenty days after the surgery, the scalp was seen to have survived well, and hair developed gradually. Pressure ulcers developed in a small part of the occipital region. Two and a half years after the accident, anterior and posterior
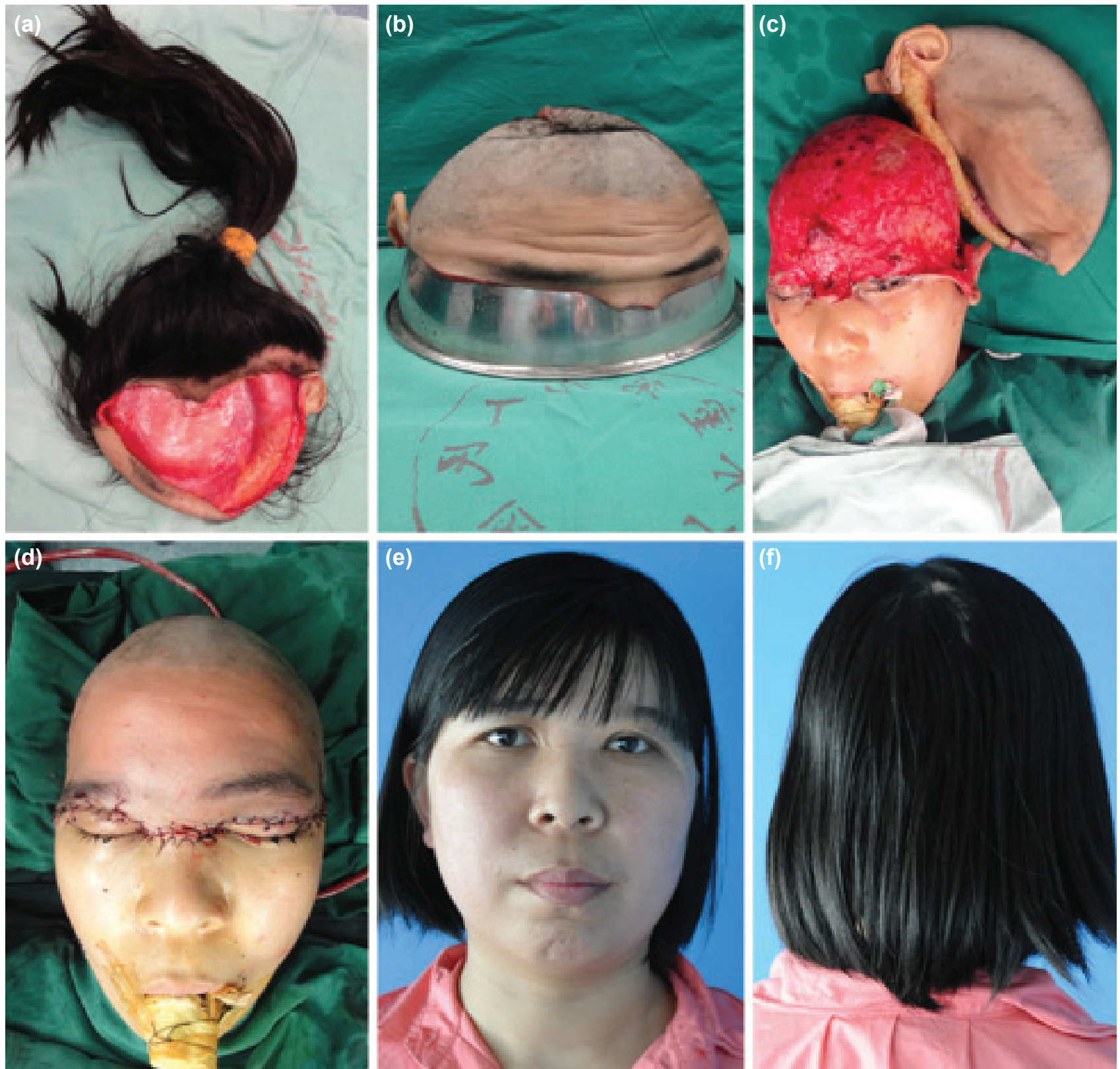

Figure 1. (a) The intact scalp was carefully removed from the machine. The total scalp was avulsed, including the ear, eyelids, eyebrows, forehead, and part of the nose. (b) Shaving of the long hair. (c) Vein grafts were anastomosed to the arteries on the patient's head and veins on the avulsed scalp. All pre-transplant preparation was completed. (d) Excellent blood supply was established for all of the avulsed scalp after vascularized replantation. (e) and (f) 2.5 years after microsurgery, good form and function of almost all the hair-bearing scalp, ear, eyelids, eyebrows, forehead, and part of the nose were achieved. 
views revealed that the entire hair-bearing scalp survived well (Figure le, f).

Case 2- A 42-year-old woman had her hair caught in a roller machine while at work, and the entire hair-bearing scalp, nasal area, frontal area, right ear, and bilateral eyelids and eyebrows were avulsed, with a connection only in the left nuchal area (Figure 2a). Associated injuries included left elbow dislocation with a left-sided olecranon fracture and ulnar nerve injury. She was conscious upon presentation to the ED. Blood loss was estimated to be approximately $1800 \mathrm{ml}$ (Figure 2b). Ini- tially, $1000 \mathrm{ml}$ of blood and Ringer's solution were transfused to correct the massive blood loss, and replantation was performed shortly after her condition was stabilized and other associated injuries were ruled out. The superficial temporal arteries and veins on both sides of the head were identified for anastomosis, and vein grafts from the dorsum of the foot were used to replace the crushed vessels. Total ischemia time was 13 hours. At the end of the surgery, the whole scalp appeared well perfused as reflected in the pink skin color (Figure $2 c$ ). Four days after surgery, the scalp appeared to have survived well when the dressing was changed for the first
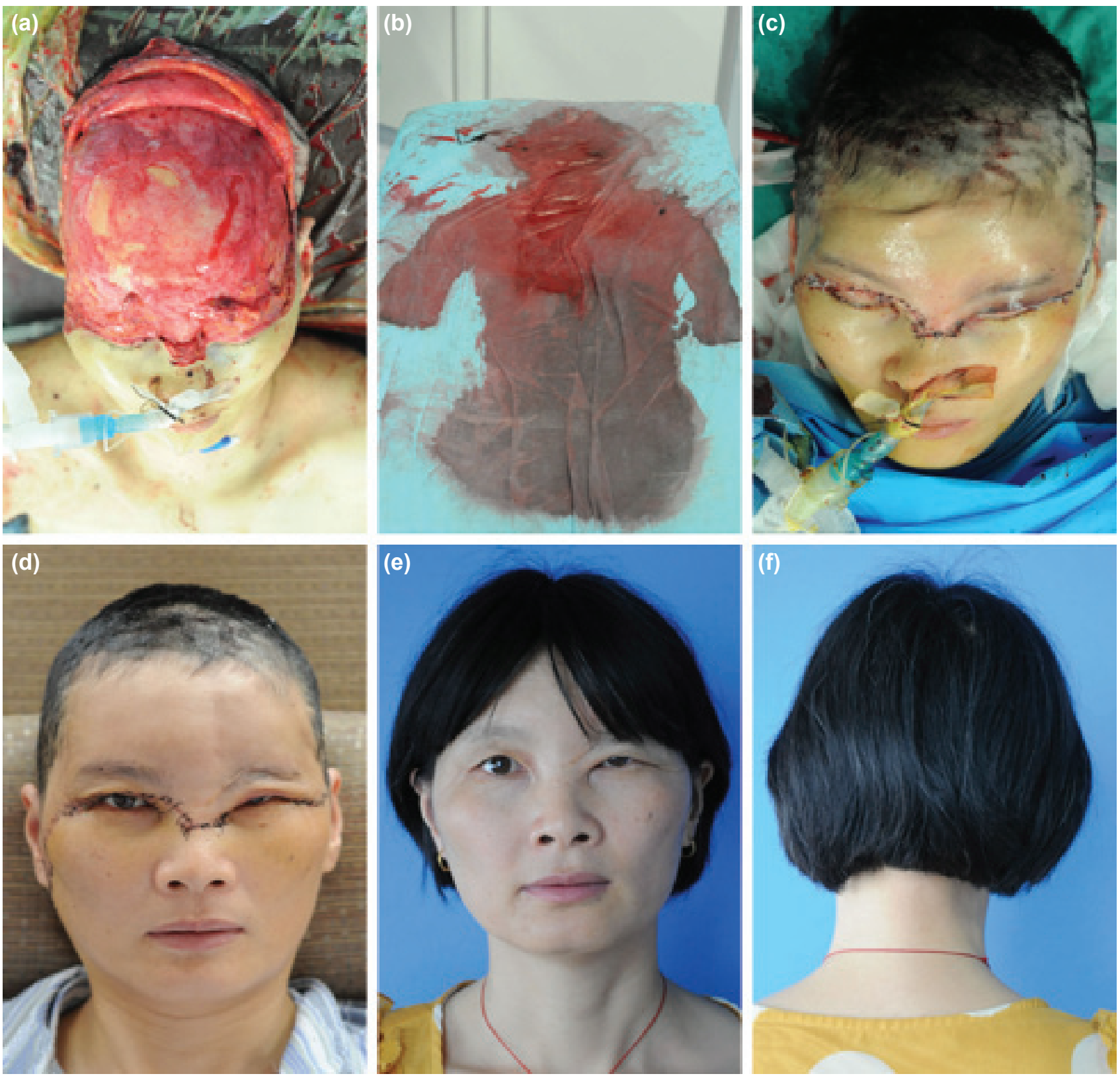

Figure 2. (a) The avulsed scalp involved the entire hairy scalp, nasal and frontal area, right ear, and bilateral eyelids and eyebrows, with a connection only in the left nuchal area. (b) Image of the blood loss soaking the sheets in the immediate vicinity of the patient. (c) At the conclusion of surgery, the whole scalp showed good blood supply as demonstrated by the pink skin color. (d) Twelve days after the accident, almost all of the scalp was seen to have survived well, and hair developed gradually when the stitches were removed. (e) and (f) 2 months after replantation, good form and function of the complete avulsed tissues and organs were achieved. 
time. Fifteen days after the accident, almost all of the scalp remained viable, and hair developed gradually (Figure $2 \mathrm{~d}$ ). Her associated elbow injuries were addressed by the orthopedic surgery team at the time of her initial scalp replantation. At the one-year follow-up, protective sensibility returned in the replanted scalp, and normal function of the amputated frontalis muscle was restored. The patient was satisfied with the eventual outcome of the reconstruction (Figure 2e, f).

\section{DISCUSSION}

Total scalp avulsion is a fairly rare and serious injury, usually the result of high-speed rotating machinery coming in contact with the patient's hair. Successful scalp replantation has been carried out in our department since $1991,,^{7,9,10]}$ and many cases, including pediatric total scalp avulsion, have been published by our department with improvements in the microsurgical technique. ${ }^{[7, I I]}$ In addition to the microsurgical technique, preoperative evaluation and preparation in the ED are considered to be an important part of successful salvage of the avulsed scalp.

Scalp avulsion, although rare, represents a true emergency upon presentation to the ED. The scalp-related injuries can be addressed only after establishing a definitive airway, stabilizing hemodynamics, and assessing for other injuries. Scalp avulsion is accompanied by the potential for hemorrhagic shock, which should be corrected first. Hemorrhage from head and facial trauma alone resulting in systemic shock occurs rarely, except in cases of extensive scalp avulsion injuries. Bleeding from the superficial temporal artery, supraorbital artery, occipital artery, facial artery, or a combination of these is most commonly encountered and can usually be controlled, at least temporarily, by applying a pressure dressing to the wound. Accurate evaluation of the blood loss is difficult. Our estimation of bleeding volume is up to 1600 $\mathrm{ml}$. Early blood transfusion and intravenous administration of Ringer's solution are mandatory, and every effort should be made to decrease the operative time to prevent substantial intraoperative blood loss.

Due to the extensive blood supply to the scalp, hemorrhaging of the scalp often appears profuse and always heightens suspicion of intracranial and cervical damage. To avoid missing any scalp-related injuries due to an inadequate examination, patients should be examined thoroughly during the secondary survey. Total scalp avulsion injuries are potentially devastating and may often include eyebrow, eyelid, nasofrontal, and ear avulsion. Assessment of the level and scope of scalp avulsion is helpful to choose the blood vessels available for anastomosis. Every attempt should be made to replant or revascularize as much of the avulsed scalp as possible.

Traction force and impact injury often result in cervical spine and brain injuries. Cervical spine and brain computed tomography should be taken in all patients to exclude surgical contraindications. This workup for scalp replantation should be mandatorily performed to exclude any associated life-threatening injuries that would take precedence over the scalp replantation.

Contraindications to replantation include severe shearing force causing extensive vessel loss or damage within the avulsed scalp and inability to identify an artery or vein, lengthy warm ischemia time (more than 30 hours) of the scalp, and unfavorable preservation of the avulsed scalp.

According to our replantation procedures, debriding the avulsed scalp, preparing the recipient site and harvesting venous grafts from the lower extremity are carried out at the same time. Performing these steps simultaneously facilitates a shortened ischemic time of the avulsed scalp and aids in the reduction of further blood loss intraoperatively.

Shaving of the hair is necessary to avoid missing additional lacerations and to remove foreign body fragments lodged in the long hair. Exposed blood vessels are often accompanied by intimal wall damage and are often unsuitable for anastomosis or grafting. We often harvest vein grafts to replace them. In order, the selection of blood vessels is as follows: superficial temporal artery, supraorbital artery, and occipital artery, depending of course on the condition of the vessels available. Based on our experience, bilateral blood supply and venous drainage are necessary for survival of the total scalp after replantation. In addition, intraoperative hypotension $(80 / 50 \mathrm{mmHg})$ may be necessary to reduce blood loss. Blood transfusion was carried out before and after surgery but was rarely required intraoperatively. As such, blood draws were frequently performed to assess for associated electrolyte abnormalities.

Postoperative care is also important. Dressing changes in our experience are best performed four days after replantation in order to prevent movement of the scalp and damage to the vascular anastomosis. Halo application and early changes in head position are necessary to avoid the formation of occipital pressure ulcers.

Conflict of interest: None declared.

\section{REFERENCES}

1. Miller GD, Anstee EJ, Snell JA. Successful replantation of an avulsed scalp by microvascular anastomoses. Plast Reconstr Surg 1976;58:133-6.

2. Buncke HJ, Rose EH, Brownstein MJ, Chater NL. Successful replantation of two avulsed scalps by microvascular anastomoses. Plast Reconstr Surg 1978;61:666-72. CrossRef

3. Biemer E, Stock W, Wolfensberger C, Ingianni G, Götz WD. Successful replantation of a totally avulsed scalp. Br J Plast Surg 1979;32:19-21.

4. Tantri DP, Cervino AL, Tabbal N. Replantation of the totally avulsed scalp. J Trauma 1980;20:350-2.

5. Hentz VR, Palma CR, Elliott E, Wisnicki J. Successful replantation of a totally avulsed scalp following prolonged ischemia. Ann Plast Surg $1981 ; 7: 145-9$. CrossRef 
6. Yaffe B, Shvoron A. Successful replantation of a totally avulsed scalp. J Reconstr Microsurg 1986;2:171-3. CrossRef

7. Cheng K, Zhou S, Jiang K, Wang S, Dong J, Huang W, et al. Microsurgical replantation of the avulsed scalp: report of 20 cases. Plast Reconstr Surg 1996;97:1099-108. CrossRef

8. Sykes LN Jr, Cowgill F. Management of hemorrhage from severe scalp lacerations with Raney clips. Ann Emerg Med 1989;18:995-6. CrossRef
9. Wang SL. Microvascular anastomosis in replantation of 6 avulsed scalps. [Article in Chinese] Zhonghua Wai Ke Za Zhi 1992;30:625-7, 37.

10. Zhou S, Chang TS, Guan WX, Chen KX, Wang SL, Cao YL, et al. Microsurgical replantation of the avulsed scalp: report of six cases. J Reconstr Microsurg 1993;9:121-9. CrossRef

11. Liu T, Dong J, Wang J, Yang J. Microsurgical replantation for child total scalp avulsion. J Craniofac Surg 2009;20:81-4. CrossRef

\section{OLGU SUNUMU - ÖZET}

\section{Travmatik total kafa derisi avülsiyonunun mikrocerrahi replantasyonla acil tedavisi Dr. Zhaohua Jiang, Dr. Shengli Li, Dr. Weigang Cao}

Shanghai Jiao Tong Üniversitesi Tıp Fakültesi, Shanghai Dokuzuncu Halk Hastanesi, Plastik ve Rekonstrüktif Cerrahi Bölümü, Shanghai, Çin Halk Cumhuriyeti

Total kafa derisi avulsiyonu seyrek görülen, sıklıkla saçlı deride defektlere yol açan, hatta yaşamı tehdit edici olabilen ciddi bir yaralanmadır. Kafa derisi avulsiyonunda mikrocerrahiyle saçlı derinin replantasyonu ilk tedavi seçeneğidir. Bu yazıda, total kafa derisi avulsiyonu olan iki olguda mikrocerrahi replantasyon tekniğini anlattık. Avulsiyona uğramış kafa derisi saçlı kafa derisi, alın, göz kapağı, kulak ve yüzün bir bölümünü içermekteydi. Acil serviste ilk tedavi hızlı bir fiziksel inceleme sonrası erkenden hemorajik şoku düzeltmek için kan transfüzyonu, intravenöz rehidrasyon ile yaranın tamponla bastırımasından ibarettir. Replantasyondan önce ameliyat öncesi dönemde, eşlik eden yaşamı tehdit edici yaralanmaları ekarte etmek için tam bir travma araştırması yapılmalıdır. İki olguda tam olarak avülsiyona uğramış dokular ve organlar morfoloji ve fonksiyonlarına kavuşmuştur. Başarılı replantasyonlar diğer prosedürlere göre en iyi estetik ve fonksiyonel sonuçları sağlayabilmektedir. Avulsiyone kafa derisinin başarıı onarımında mikrocerrahi tekniğe ilaveten acil serviste ameliyat öncesi değerlendirme ve hazırlığın önemli olduğu düşünülür.

Anahtar sözcükler: Acil servis; avulsiyon; kafa derisi; mikrocerrahi; replantasyon.

Ulus Travma Acil Cerr Derg 2014;20(I):66-70 doi: 10.5505/tjtes.20।4.68253 